\title{
Preferential Trade Agreements under Declining American Hegemony
}

\author{
Kaoru Ishiguro ${ }^{1}$ \\ ${ }^{1}$ Graduate School of Economics, Kobe University, Hyogo, Japan \\ Correspondence: Kaoru Ishiguro, Graduate School of Economics, 2-1 Rokkodai, Nada-ku, Kobe, Hyogo, 657-8501, \\ Japan. Tel: 81-788-036-835.
}

Received: December 25, 2017

doi:10.5430/ijfr.v9n1p163

Accepted: January 9, $2018 \quad$ Online Published: January 10, 2018

URL: https://doi.org/10.5430/ijfr.v9n1p163

\begin{abstract}
We examine the international determinants of the formation of preferential trade agreements (PTAs) according to the theory of hegemonic stability. The main conclusions are as follows. First, as the theory of hegemonic stability argues, the lack of a stable hegemon fosters the formation of PTAs. When hegemony is measured by trade share and investment share in the global economy, the erosion of hegemony fosters PTAs. Second, hegemony measured by GDP share has a positive effect on PTA formation; however, this measure is not consistent with the theory's prediction. Third, improvement in the level of democracy worldwide is unrelated to the formation of PTAs.
\end{abstract}

Keywords: PTA, hegemonic stability theory, hegemony, international determinant

\section{Introduction}

Preferential trade agreements (PTAs) or regional trade agreements (RTAs) exert an important influence on both domestic economies and the global economy, by assuring free access among the member states. The bloom of PTAs is considered one of the most important economic phenomena in the world economy in the 30 years since the Cold War. The World Trade Organization (WTO) reports that by 2017, there were more than 300 signed PTAs still in force (see Figure 1).

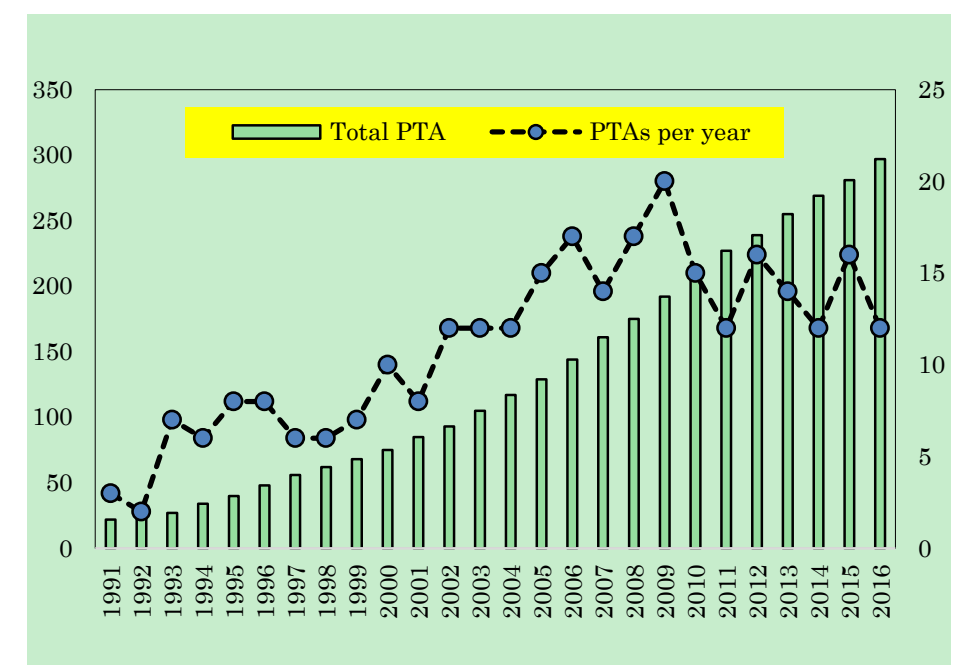

Figure 1. Total PTAs and PTAs per year, 1991-2016

Source. WTO.

What factors can explain the varying rate of PTA formation since the Cold War? Why do countries join PTAs? A PTA is a trade pact among countries that reduces tariffs to the countries who are members of the agreement, while discriminating against countries outside the pact. The purpose of this study is to explain the international determinants of PTA formation since the Cold War. Mansfield and Milner (2012) point out crucial factors to consider based on the theory of hegemonic stability (Krasner, 1976; Gilpin, 1981, 1987; Keohane, 1984; Lake, 1988). We 
expand the types of systemic factors that might be considered as potential influences, and offer a more comprehensive understanding of the driving forces that promote PTAs globally.

We investigate the effects of international factors on the formation of PTAs since the Cold War, using the following systemic variables: hegemony, strategic interaction among states and among PTAs, the global business cycle, and expanding democracies. Hegemony is measured using alternative terms: trade share, investment share, GDP share, U.S. investment (mean), and U.S. investment (stock). The strategic interaction among states and among PTAs, and international diffusion are measured by the total number of PTAs and total number of states. The global business cycle is measured with the increment of gross world production (GWP) per year. We also address the effects of diffused democracy, measured by the proportion of democratic states in the world. In addition, we introduce the effects of conflicted negotiations in the WTO, measured by the Doha round dummy variable.

Our main findings are as follows. First, as the theory of hegemonic stability argues, the lack of a stable hegemon fosters the formation of PTAs. When hegemony is measured by trade share and investment share in the global economy, the decreased measures for these factors foster PTAs. Second, hegemony measured by GDP share has a positive effect on PTA formation, although the measure does not support the theory's prediction. Third, improvement in the level of democracy worldwide is unrelated to the formation of PTAs.

This paper is organized as follows. Section 2 reviews the existing literature to discuss international factors, especially hegemony, in explaining PTA formation. In Section 3, we explain the method used to analyze the data, and present the econometric model. Section 4 reports the empirical results and some discussion. Finally, in Section 5, we summarize our conclusions.

\section{Literature Review}

What are the international determinants of PTA formation? In addition to analysis that focuses on the domestic factors explained by a political economy theory, there are many previous studies that focus on the effects of international factors, such as hegemony, strategic interaction and international diffusion, the global business cycle, and diffused democracy.

\subsection{Hegemony}

Many studies have stressed the effect of hegemony on the international system of PTA formation. They argue that international economic stability is a collective good, and without a strong hegemon, suboptimal amounts of the collective good will be produced (Kindleberger, 1973; Gilpin, 1975; Lake, 1988). PTAs are then outgrowths of the international economic instability fostered by the decline of the hegemon. Many researchers say that the current increase in PTAs was triggered by the U.S. decision regarding the North American Free Trade Agreement (NAFTA), resulting from the decline in its economic power, and the troubled negotiations at the GATT round in the early 1980s (Pomfret, 1988; Bhagwati \& Panagariya, 1996).

Gilpin $(1975,1981,1987)$ and Krasner (1976) point out that the decline of hegemony promotes an increase in PTAs. As Gilpin (1981) argues, states that enter into international relationships always build an international structure to pursue their interests, establishing an international system. A state is likely to change this system if the expected benefits from the change are larger than its costs; systemic equilibrium will not be achieved until there is no profit to be gained from changing the system. In theoretical research, Gilpin $(1975,1987)$ and Krasner (1976) have shown that when an open multilateral trading system is unsustainable because of the decline of a hegemon, PTAs that create discriminatory blocs are formed as a suboptimal solution. The decline of hegemony undermines the foundation of the multilateral trading principle, and thus, as Gilpin (1987: 230) argues, "Bilateralism and similar arrangements, although they have their own dangers, may be the only way to move even haltingly in the direction of a more open trading system."

However, there is also the opposing argument of Lake (1988) and Gowa (1994) regarding the role of hegemonic decline. They suggest that, while hegemons always have enough market power to set a tariff that is an optimal tariff for them, other non-hegemonic countries are eager to create PTAs to offset the optimal tariff of a hegemon. Therefore, if the hegemon declines, the need for sustaining PTAs also declines. As Lake (1988) point outs, the international trade instability between 1930 and 1939, together with the further decline of Britain, finally led to an increase in protectionism.

According to the theory of hegemonic stability, increased PTA formation is often attributed to the declining economic power of the U.S., and the troubled negotiations within GATT, as well as the U.S. government's decision to pursue unilateralism (Pomfret, 1988; Krugman, 1993). In response to the U.S.'s regional behavior, as demonstrated by the NAFTA, which was effective in 1994, other advanced countries began forming PTAs of their 
own. One example is the effort for Western European countries to form a single market, known as the European Union (EU).

\subsection{Strategic Interaction and International Diffusion}

Studies of PTA formation often highlight the strategic interdependence among both PTAs and countries. Some studies find that PTA formation and diffusion have a positive correlation or demonstration effects (Pomfret, 1988; Oye, 1992, Yarbrough \& Yarbrough, 1992; Baldwin, 1995). The countries outside the existing PTAs (outside the bloc) fear competitive disadvantages, and thus, have an incentive to create competitive advantages and realize familiar gains by establishing additional PTAs. Countries joining PTAs also encourage other countries to join, and therefore the formation of a PTA does stimulate other PTAs.

As Pomfret (1988) argues, the discriminating economic bloc often creates economic pressure for imitation. As a result, PTAs tend to proliferate either because of a demonstration effect or to protect legitimate interests. If some PTAs benefit their members, this fosters the creation of additional PTAs by countries eager to obtain similar gains. In addition, PTAs increase their member countries, increasing inside firms' market power, and consequently, their bargaining power. Formation of a PTA erodes the bargaining power of countries and firms that are not members, and thus other countries are likely to form PTAs as a reaction. As we saw above, NAFTA spurred PTAs in both the Western Hemisphere and Asia-Pacific regions.

\subsection{Global Business Cycle}

In addition to international political factors, global business cycles have also been argued to affect PTA formation. As Mansfield and Milner (2012) point out, the effects of global business cycles, especially global recessions, on the formation of PTAs depends on whether PTAs tend to decrease or increase competitive pressure on domestic import-competing firms that are more protective than export-competing firms.

The effect on the rate of PTA formation caused by the global business cycle is controversial among the theoretical analyses. Global recessions may stimulate PTA formation because recessions depress the demand for goods and services and reduce employment, creating incentives for firms to block their markets and form PTAs. Matti (1999) considers that the decrease in profits caused by recessions stimulates import-competing firms to seek the establishment of PTAs.

In contrast, global recessions may depress PTA formation. In recessions, import-competing firms tend to be more protective and likely to resist PTA formation because within PTAs, import-competing firms face severe competition. On the other hand, some countries may tend to form PTAs to insulate against the adverse flow of trade from future disruptions. Yarbrough and Yarbrough (1992) argue that those countries that are achieving flourishing trade are likely to establish PTAs as a precaution against the risk of future recessions.

\subsection{Democracy and Domestic Factors}

As seen in the literature review, many studies have focused on the mechanism through which international factors affect the formation of PTAs. However, the international factors are not sufficient for explaining the establishment of PTAs, because the decision to enter a PTA or not depends on whether joining a PTA yields benefits for each country's political leader (Grossman \& Helpman, 1995; Gilligan, 1997; Milner, 1997; Maggi \& Rodrigues-Clare, 1998, 2007; Staiger \& Tabellini, 1999; Mitra, 2002; Mansfield, Milner, \& Rosendorff, 2002; Chase, 2003, 2005).

Mansfield and Milner (2012) argue that democracies are more likely to enter PTAs than nondemocracies. Democratic institutions often provide considerable information about the merits and demerits of PTAs and actions of member countries, and thus heighten the possibility that those countries will enter PTAs. However, autocrats provide less opportunity to argue the merits and demerits of PTAs. According to Mansfield and Milner (2012), the spread of PTAs is linked to the spread of democracy after World War II.

Mansfield et al. (2002) state that leaders are likely to sign PTAs as a reassurance for free-trade interest groups in a democratic society. PTAs are established by governments to show that they are not enforcing protective policies, thereby reducing the risk of being ousted. However, such logic can be easily conjectured to only apply to democracies. Therefore, establishing PTAs is easier in democracies than in nondemocracies, and the increasing rate of democracies positively affects PTA formation rates.

Maggi and Rodrigues-Clare $(1998,2007)$ also provide an approach of political credibility. To avoid pressure from protectionist interest groups, governments may form trade agreements to make their attitude toward free trade more credible. Similarly, Staiger and Tabellini (1999) argue that, in comparison with domestic institutions, entering an international free trade agreement is more credible, which allows the government to resist attracting pressure from 
interest groups. Mitra (2002) develops the analysis of Maggi and Rodrigues-Clare (1998), arguing that protectionism not only creates costs because of investment distortion, but also substantial political costs posed by the policy shift of governments, and thus governments make commitments to defend against protectionists' demands.

There is an alternative view regarding the establishment of trade agreements. The domestic free trade-oriented interest groups pressure the government to pursue trade agreements because they can benefit from the agreements. Gilligan (1997), Milner (1997), and Chase (2003, 2005) claim that sectors such as export-oriented industries can gain from PTAs by freely accessing foreign markets while debarring their competitors outside the PTAs. Since these industries have economies of scale, they can reduce the per-unit cost of production. Thus, pressure on governments to pursue PTAs mainly comes from sectors in the export-oriented industries.

\section{Method}

Even though many analyses theoretically argue the influence of numerous factors, there are few empirical analyses that indicate which international factors have significant effects on the formation of PTAs. Mansfield and Milner (2012) make an empirical effort to assess the different influences of international factors on the frequency of PTA formation. In addition, they also estimate how the share of democratic states in the world affects PTA formation. We reexamine their empirical results, and reveal statistically significant international factors.

\subsection{Variables and Basic Statistics}

We build a statistical model to provide a comprehensive understanding of the effect of international factors on PTA formation. Table 1 presents the variables and definitions used for our statistical analysis. The dependent variable is the total number of PTAs that exist each year. Form PTA is the number of PTAs formed from year $t-1$ to year $t$. We use the PTA data reported by the WTO.

Table 1. Variables and definitions

\begin{tabular}{ll}
\hline Variable & Definition \\
\hline $\begin{array}{l}\text { Form PTA } \\
\text { Hegemony (trade) }\end{array}$ & $\begin{array}{l}\text { number of PTAs formed from year } t \text {-1 to year } t . \\
\text { the most commercial country's share of total global trade (the sum of global } \\
\text { imports and exports) in year } t-1\end{array}$ \\
Hegemony (invest) & $\begin{array}{l}\text { the most commercial country's share of total global average investment } \\
\text { amounts every } 5 \text { years from } 1991 \text { to } 2012\end{array}$ \\
Hegemony (GDP) & the most commercial country's share of total global GDP from 1991 to 2012 \\
U.S. invest (mean) & average investment amounts by the U. S. every 5 years from1991 to 2012 \\
U.S. invest (stock) & $\begin{array}{l}\text { accumulated investment amounts by the U.S. } \\
\text { change in gross world product from year } t-2 \text { to year } t-1\end{array}$ \\
Democracy & share of democratic states in the international system in year $t-1$ \\
PTA & total number of existing PTAs in year $t-1$ \\
Number of Countries & total number of states in the world in year $t-1$ \\
Doha Round & dummy variable equaling 0 until 2003 and 1 from 2004 to 2012 \\
\hline
\end{tabular}

Based on the variables used by Mansfield and Milner (2012), the independent variables include hegemonic factors, U.S. factors, and other factors. We use these variables to verify whether PTAs are created by the economic instability caused by the decline of a stable hegemony. The hegemonic factors are classified into Hegemony (trade), Hegemony (invest), and Hegemony (GDP). Hegemony (trade) is measured by the most commercial country's share of total global trade (the sum of global imports and exports) in year t-1 from 1991 to 2012. Hegemony (invest) is hegemony measured by the most commercial country's share of total global average investment amount every 5 years from 1991 to 2012. Hegemony (GDP) is hegemony measured by the most commercial country's share of total global GDP in year $\mathrm{t}$ from 1991 to 2012. These three independent variables are the international factors that we consider as substantial properties of the global system affecting PTA formation.

We also use U.S. factors, which represent another proxy of hegemony. The U.S. factors include U.S. Invest (mean) 
and U.S. Invest (stock). U.S. Invest (mean) is the average investment amount made by the U.S. worldwide every 5 years from1991 to 2012. U. S. Invest (stock) is measured by the accumulated worldwide U.S. investment amount in year $t$.

In addition, based on the variables used by Mansfield and Milner (2012), we also consider the variable Democracy as a measure of the proportion of democratic states in the international system in year $\mathrm{t}-1$. GWP is measured by the change in gross world product from year $t-2$ to year $t-1$. We use it to confirm whether and how the global business cycle influences the formation of PTAs. PTA is total number of existing PTAs in year t-1, which is a measure of the strategic interaction and international diffusion of PTAs. Number of Countries is measured by the total number of states worldwide in year $t-1$, which is also a strategic interaction variable. Doha Round is a dummy variable equaling 0 until 2003, and 1 from 2004 to 2012, which reflects a measure of the conflicted negotiations under the Doha round in the WTO.

Table 2 displays the descriptive statistics for all variables.

Table 2. Descriptive statistics

\begin{tabular}{lllll}
\hline Variable & Mean & Std. Dev. & Min & Max \\
\hline Form PTA & 9.727 & 4.300 & 3 & 20 \\
Hegemony (trade) & 0.132 & 0.016 & 0.103 & 0.158 \\
Hegemony (invest) & 0.210 & 0.023 & 0.172 & 0.250 \\
Hegemony (GDP) & 0.274 & 0.028 & 0.219 & 0.325 \\
U.S. invest (mean) & 197724.2 & 102228.2 & 51364.8 & 362762.5 \\
U.S. invest (stock) & 1331926 & 1147319 & 30982 & 3743924 \\
GWP & 2.078 & 1.528 & -2.679 & 4.113 \\
Democracy & 0.441 & 0.037 & 0.371 & 0.497 \\
PTA & 106.046 & 62.221 & 22 & 220 \\
Number of Countries & 186.182 & 8.556 & 159 & 193 \\
Doha Round & 0.545 & 0.509 & 0 & 1 \\
\hline
\end{tabular}

Source. Form PTA, PTA, and GWP: WTO. Hegemony (trade): IMF. Hegemony (invest), Hegemony (GDP), U.S. invest (mean), and U.S. invest (stock): UNCTAD. Democracy: Polity IV Project. Number of Countries: UN.

Table 2 provides information about the hegemonic factors, U.S. factors, and other factors. For each variable, the data includes information from 1991 to 2012. Form PTA represents the number of PTAs formed each year; the largest number is 20, the smallest number is 3, and the average of all years is 9.727 PTAs. Hegemony (trade) represents the most commercial country's share of total global trade. The largest share is $15.8 \%$, the smallest share is $10.3 \%$, and the average share is $13.2 \%$. Hegemony (invest) denotes the most commercial country's share of total global investment; the largest share is $25.0 \%$, the smallest share is $17.2 \%$, while the average share is $21.0 \%$. Hegemony $(G D P)$ represents the most commercial country's share of total global GDP, where the largest share is $32.5 \%$, the smallest share is $21.9 \%$, and the average share is $27.4 \%$.

3.2 Model

Equation (1) is the model for the empirical analysis. We assume this linear model:

$$
\begin{aligned}
\text { Form PTA }=\beta_{0} & +\beta_{1} \text { Hegemony }(\text { trade })+\beta_{2} \text { Hegemony }(\text { invest }) \\
& +\beta_{3} \text { Hegemony }(\text { GDP })+\beta_{4} \mathrm{U} . \mathrm{S} \text {. Invest (mean) } \\
& +\beta_{5} \text { U.S. Invest }(\text { stock })+\beta_{6} G W P+\beta_{7} \text { Democracy }+\beta_{8} P T A \\
& +\beta_{9} \text { Number of Countries }+\beta_{10} \text { Doha Round }+u_{t}
\end{aligned}
$$

where $\beta_{0} \sim \beta_{10}$ represent the unknown parameters, and $u_{t}$ is the error term.

\section{Results and Discussion}

We use a negative binominal regression for the estimation, which is an event count model, because the formation of PTAs in each year exhibits correlation, and a Poisson model cannot be used when events are dependent or correlated. Table 3 shows the estimated results of negative binominal regression using equation (1). For the independent variables, Model 1 uses the hegemonic factors, Model 2 estimates using the hegemonic factors and U.S. factors, 
Model 3 estimates using the other factors, and Model 4 estimates using all factors simultaneously.

Table 3. Estimated results of negative binominal regression

\begin{tabular}{|c|c|c|c|c|}
\hline & Model 1 & Model 2 & Model 3 & Model 4 \\
\hline \multirow[t]{2}{*}{ Hegemony (trade) } & -12.66249 & $-62.92213^{* *}$ & & $-71.91168 * *$ \\
\hline & (23.730 44) & (28.421 72) & & (33.648 63) \\
\hline \multirow[t]{2}{*}{ Hegemony (invest) } & 3.351133 & $-14.77162 * *$ & & $-15.42428 * *$ \\
\hline & (3.630 089) & $(6.536730)$ & & $(6.856886)$ \\
\hline \multirow[t]{2}{*}{ Hegemony (GDP) } & 1.879227 & $25.59105^{* *}$ & & $28.37616^{* *}$ \\
\hline & (7.456 443) & (10.369 32) & & (11.303 69) \\
\hline \multirow[t]{2}{*}{ US Invest (mean) } & & $-0.0000171^{*}$ & & $-0.0000208^{*}$ \\
\hline & & $(0.00000904)$ & & $(0.0000108)$ \\
\hline \multirow[t]{2}{*}{ US Invest (stock) } & & $0.00000399 * * *$ & & $0.000004 .16^{* * *}$ \\
\hline & & $(0.00000126)$ & & $(0.00000136)$ \\
\hline \multirow[t]{2}{*}{$G W P$} & & & -0.044128 & 0.038019 \\
\hline & & & (0.041 775) & $(0.061242)$ \\
\hline \multirow[t]{2}{*}{ Democracy } & & & -5.771328 & 1.397646 \\
\hline & & & (9.407 952) & (11.857 46) \\
\hline \multirow[t]{2}{*}{ PTA } & -0.003196 & $-0.066294 * * *$ & 0.001173 & $-0.066450 * *$ \\
\hline & $(0.003651)$ & (0.024 568) & (0.004 263) & (0.026 573) \\
\hline \multirow[t]{2}{*}{ Countries Number } & $0.052867 * *$ & $0.124252 * * *$ & $0.045732 * *$ & $0.129971 * * *$ \\
\hline & $(0.022852)$ & $(0.031816)$ & $\left(\begin{array}{lll}0.020 & 162\end{array}\right)$ & (0.035 387) \\
\hline \multirow[t]{2}{*}{ Doha Round } & 0.169043 & 0.720950 & 0.429091 & 0.745877 \\
\hline & $(0.444374)$ & (0.555 117) & (0.327 098) & $(0.556465)$ \\
\hline \multirow[t]{2}{*}{ Constant } & $-6.914887 *$ & $-11.75464 * * *$ & -3.969664 & $-12.44289^{* * *}$ \\
\hline & (3.748 028) & $(4.074479)$ & (3.827 109) & (5.022 996) \\
\hline Obs & 22 & 22 & 22 & 22 \\
\hline $\mathrm{R}^{2}$ & 0.545429 & 0.888590 & 0.527476 & 0.900335 \\
\hline Adjusted $\mathrm{R}^{2}$ & 0.363601 & 0.820030 & 0.379812 & 0.809731 \\
\hline
\end{tabular}

Note. $* * * 1 \%, * * 5 \%, * 10 \%$ represent the significance levels based on $p$ values. The value in parentheses is the standard error.

In Model 4, the significant hegemonic factors are Hegemony (trade), Hegemony (invest), and Hegemony (GDP). The significant U.S. factors are U.S. Invest (mean) and U.S. Invest (stock), while significant other factors are PTA and Countries Number.

\subsection{Hegemonic Factors}

In Model 4, the estimated coefficients of Hegemony (trade) and Hegemony (invest) are both negative and statistically significant, while Hegemony (GDP) is positive and statistically significant. The former is consistent with the theory of hegemonic stability and the estimated results found by Mansfield and Milner (2012), implying that establishment of PTAs can be stimulated by a decline in hegemony. This suggests that increasing PTAs as a suboptimal solution is reasonable to adapt to circumstances where an open multilateral trading system is lacking because of the decline of a hegemon. However, the interesting thing is that Hegemony (GDP) shows the opposite result, suggesting that, at least based on GDP share, a decline of hegemony also decreases the rate of PTA establishment. We obtain the same result in the estimation of Model 2. 


\subsection{U.S. Factors}

In Model 4, the estimated coefficient of U.S. Invest (mean) is negative and statistically significant, while the coefficient of U.S. Invest (stock) is positive and statistically significant. The former implies that the decline of the world's existing hegemon (the U. S.) raised the rate of PTA establishment. In contrast, the latter coefficient is estimated for investment stock. Because investment can only produce the desired result after some years, the expansion of investment stock may be viewed as continuous economic growth in the U.S. economy and the global economy. The positive coefficient implies that PTA formation can be boosted by U.S. investment stock or systemic continuous economic expansion.

\subsection{Other Factors}

The positive but statistically insignificant estimated coefficient of GWP is consistent with the results of Mansfield and Milner (2012). This implies that there is no tendency indicating that the rate of PTA formation increases in expansion periods of the global business cycle. This result does not support the view of Yarbrough and Yarbrough (1992), who argued that countries that achieve flourishing trade with each other have a tendency to form PTAs because they are afraid of the risk of recession in the future.

The results of Model 4 show that the estimated coefficient of Democracy is positive but statistically insignificant, whereas Mansfield and Milner (2012) advocated that democracies affect PTA formation. According to Mansfield et al. (2002), total tariffs between democratic countries are lower than total tariffs between democratic countries and autocratic countries. However, they are higher than total tariffs between autocratic countries when the leaders are more liberal than the legislatures of democratic countries. This can help us explain why our estimated result is statistically insignificant. If autocratic countries increase, countries among them whose leaders are liberal enough foster PTA establishment. If democratic countries increase, in other words, autocratic countries decrease, the two opposite effects will counteract each other, resulting in a statistically insignificant estimated coefficient. One effect is the boost in PTA establishment caused by the increase in democratic countries. The other is the effect where PTA establishment is impeded, caused by the decrease in autocratic countries controlled by liberal leaders.

The estimated coefficient of PTA in Model 4 is negative and statistically significant, consistent with the estimated results of Mansfield and Milner (2012). Regarding strategic interaction and international diffusion, there is an adverse relationship between the number of existing PTAs in the global system and additional PTAs formed per year. If we accept these results, some theoretical analyses are not empirically supported. Pomfret (1998), Oye (1992), and Yarbrough and Yarbrough (1992) argue that there is a positive correlation in the rate of PTA formation because of the incentives of outside countries to obtain the familiar benefits. We can also see this same result in the estimation of Model 2, while the coefficient is statistically insignificant in the estimation of Model 1.

While the estimated coefficient of Countries Number is positive and statistically significant, the coefficient of Doha Round is statistically insignificant. As the number of countries increases, so does the establishment of PTAs. However, the troubled negotiations in the Doha round of the WTO did not affect the establishment of PTAs.

\section{Conclusion}

In this study, we have examined the international determinants of PTA formation according to the theory of hegemonic stability. Mansfield and Milner (2012) point out crucial factors to consider based on the theory of hegemonic stability. We expand the types of systemic factors that might be considered as potential influences, and offer a more comprehensive understanding of the driving forces that promote PTAs globally.

The main conclusions are as follows. First, as the theory of hegemonic stability argues, the lack of a stable hegemon may foster the formations of PTAs. For hegemony measured by trade share and investment share in the world economy, as well as the 5-year mean investment of the U.S., a decrease in the measurements of the factors fosters PTAs. Second, hegemony measured by GDP share and U.S. investment stock has a positive effect on PTA formation. These factors are not consistent with the theory's prediction. Third, an increase in the level of democracy worldwide is unrelated to the formation of PTAs. We could not reproduce the results of Mansfield and Milner (2012), who argued that democracy has a positive and statistically significant effect on PTA formation.

Future research includes studying the domestic factors that shape a government's decision to form PTAs, based on other theories that stress domestic politics. The domestic factors have political credibility, as explained by Maggi and Rodrigues-Clair (1998, 2007), as well as the export-oriented industries' political pressure as pointed out by Gilligan (1997), Milner (1997) and Chase (2003, 2005). 


\section{References}

Baldwin, R. (1995). A domino theory of regionalism. In R. Baldwin, P. Haaparanta, \& J. Kiander (Eds.), Expanding membership of the European Union. New York: Cambridge University Press.

Bhagwati, J., \& Panagariya, A. (1996). The economics of preferential trade agreements. Washington D.C.: AEI Press.

Chase, K. A. (2003). Economic interests and regional trade agreements: The case of NAFTA. International Organization, 57(1), 137-74. https://doi.org/10.1017/S0020818303571053

Chase, K. A. (2005). Trading blocs: States, firms, and regions in the world economy. Ann Arbor: University of Michigan Press.

Gilligan, M. J. (1997). Empowering exporters: Reciprocity, delegation, and collective action in American trade policy. Ann Arbor: University of Michigan Press.

Gilpin, R. (1975). U.S. power and the multinational corporation: The political economy of foreign direct investment. New York. Basic Books.

Gilpin, R. (1981). War and change in world politics. New York: Cambridge University Press.

Gilpin, R. (1987). The political economy of international relations. Princeton: Princeton University Press.

Gowa, J. S. (1994). Allies, adversaries, and international trade. Princeton: Princeton University Press.

Grossman, G. M., \& Helpman, E. (1995). The politics of free-trade Agreements. American Economic Review, 85, 667-90.

Keohane, R. O. (1984). After hegemony. Princeton: Princeton University Press.

Kindleberger, C. P. (1973). The world in depression. Berkeley: University of California.

Krasner, S. D. (1976). State power and the structure of international trade. World Politics, 28, 317-47. https://doi.org/10.2307/2009974

Krugman, P. (1993). Regionalism versus multinationalism. In J. de Melo \& A. Panagariya (Eds.), New dimensions in regional integration. New York: Cambridge University Press.

Lake, D. A. (1988). Power, protectionism, and free trade: International sources of U.S. commercial strategy. Ithaca, NY: Cornell University Press.

Maggi, G., \& Rodrigues-Clare, A. (1998). The value of trade agreements in the presence of political pressures. Journal of Political Economy, 106, 574-601. https://doi.org/10.1086/250022

Maggi, G., \& Rodrigues-Clare, A. (2007). A political-economy theory of trade agreements. American Economic Review, 97, 1374-1406. DOI: 10.1257/aer.97.4.1374

Mansfield, E. D., Milner, H. V., \& Rosendorff, B. P. (2002). Why democracies cooperate more: Electoral control and international trade agreements. International Organizations, 56, 477-513. https://doi.org/10.1162/002081802760199863

Mansfield, E. D., \& Milner, H. V. (2012). Votes, vetoes, and the political economy of international trade agreements. Princeton: Princeton University Press.

Matti, W. (1999). The logic of regional integration: Europe and beyond. New York: Cambridge University Press.

Milner, H. V. (1997). Industries, governments, and the creation of regional trade blocs. In E. D. Mansfield and H. V. Milner (Eds.), The political economy of regionalism. New York: Columbia University Press.

Mitra, D. (2002). Endogenous political organization and the value of trade agreements. Journal of International Economics, 57, 473-85. https://doi.org/10.1016/S0022-1996(01)00156-8

Oye, K. A. (1992). Economic discrimination and political exchange: World political economy in the 1930s and 1980s. Princeton: Princeton University Press.

Pomfret, R. (1988). Unequal trade: The economics of discriminatory international trade policies. Oxford: Basil Blackwell.

Staiger, R. W., \& Tabellini, G. (1999). Do GATT rules help governments make domestic commitments? Economics and Politics, 11, 109-144. DOI: 10.1111/1468-0343.00055

Yarbrough, B. V., \& Yarbrough, R. M. (1992). Cooperation and governance in international trade: The strategic organizational approach. Princeton: Princeton University Press. 